\title{
Residual activity of sulfentrazone and its impacts on microbial activity and biomass of Brazilian Savanna soils ${ }^{1}$
}

\author{
Virgínia Damin², Bruno da Silva Carrijo², Nathalia Almeida Costa ${ }^{2}$
}

\section{ABSTRACT}

Soil attributes may affect the residual activity and impacts of herbicides on non-target organisms. This study aimed to evaluate the residual activity of the sulfentrazone herbicide and its impacts on microbiological parameters of Brazilian Savanna soils, as well as to identify soil attributes that can be used to predict the residual activity of the herbicide in these soils. The experimental design was completely randomized, in a $6 \times 5$ factorial scheme, with 4 replications, being 5 soil types (Rhodic Acrustox; Typic Quartzpsamment; Rhodic Haplustox; Typic Humaquepts; Fluventic Dystrustepts) and 6 periods (0, 15, 30, 45, 60 and 90 days after herbicide application - DAA). The residual activity of the sulfentrazone herbicide is dependent of the soil type, and the time that the herbicide can control at least $80 \%$ of Urochloa decumbens plants ranges from 0 (Typic Humaquepts) to 38 days (Rhodic Haplustox). The bases saturation is the only soil attribute correlated with the herbicide efficacy over time, in the Brazilian Savanna soils, showing a moderate correlation up to 90 DAA. The $\mathrm{pH}$, organic matter and clay content are not correlated with the herbicide efficacy over time in these soils. Sulfentrazone reduces the microorganisms activity from 45 to 90 DAA in all the studied soils. However, it does not affect the microbial biomass carbon.

KEYWORDS: Urochloa decumbens Stapf., pre-emergent herbicides, soil microorganisms.

\section{INTRODUCTION}

Brazil is currently the biggest pesticides consumer worldwide, with herbicides representing more than $50 \%$ of the marketed products (Moraes 2019). The Midwest region has the highest rate of pesticides use per area, with an average of $16.14 \mathrm{~kg} \mathrm{ha}^{-1}$ (Bombardi 2017). The biome predominant in this region is the Brazilian Savanna, which is considered one of the 34 hotspots of biodiversity in the world

\section{RESUMO}

Atividade residual de sulfentrazone e seus impactos na atividade e biomassa microbiana de solos de Cerrado

Os atributos do solo podem afetar a atividade residual e o impacto de herbicidas em organismos não alvos. Objetivou-se avaliar a atividade residual do herbicida sulfentrazone e seus impactos em parâmetros microbiológicos de solos de Cerrado, bem como identificar atributos do solo que possam ser utilizados para a predição do efeito residual do herbicida nesses solos. Utilizou-se delineamento experimental completamente casualizado, em esquema fatorial $6 \times 5$, com 4 repetições, sendo 5 tipos de solo (Latossolo Vermelho Ácrico; Neossolo Quartzarênico Órtico; Latossolo Vermelho Distrófico; Gleissolo Melânico Distrófico; Neossolo Flúvico Tb Distrófico) e 6 períodos $(0 ; 15 ; 30 ; 45 ; 60 ;$ e 90 dias após a aplicação do herbicida DAA). A atividade residual do sulfentrazone é dependente do tipo de solo, e o tempo em que é capaz de controlar pelo menos $80 \%$ de plantas de Urochloa decumbens varia de 0 (Gleissolo Melânico Distrófico) a 38 dias (Latossolo Vermelho Distrófico). A saturação por bases é o único atributo do solo correlacionado com a eficácia do herbicida ao longo do tempo, nos solos de Cerrado, apresentando correlação moderada até 90 DAA. O pH, a matéria orgânica e o conteúdo de argila não têm correlação com a eficácia do herbicida ao longo do tempo, nesses solos. O sulfentrazone reduz a atividade de micro-organismos entre 45 e 90 DAA em todos os solos estudados. Entretanto, o carbono da biomassa microbiana não é afetado.

PALAVRAS-CHAVE: Urochloa decumbens Stapf., herbicidas pré-emergentes, micro-organismos do solo.

(Myers et al. 2000). Therefore, herbicides management strategies aiming to assure a high crop yield associated with low environmental impacts are very important to guarantee a sustainable agriculture in this region.

There are many factors affecting the behavior of herbicides in agroecosystems, such as soil properties, environmental factors, herbicides physicochemical characteristics and management strategies adopted in the areas. Nowadays, the decision on which herbicide and dose to apply are reasoned in weed species and

\footnotetext{
${ }^{1}$ Received: Mar. 26, 2021. Accepted: June 18, 2021. Published: Nov. 22, 2021. DOI: 10.1590/1983-40632021v5168340.

${ }^{2}$ Universidade Federal de Goiás, Escola de Agronomia, Goiânia, GO, Brasil.

E-mail/ORCID: virginiadamin@ufg.br/0000-0003-3811-4794; brunocarrijo@discente.ufg.br/0000-0002-3340-041X; nathalia_almeida_16@hotmail.com/0000-0003-1404-5982.
} 
their frequency in the area (Andrade et al. 2010), the selectivity of the active ingredient to the crop and the soil texture (Manzano 2013). However, soil attributes such as mineralogy, cation exchange capacity, $\mathrm{pH}$, organic carbon, water content and microbial communities may have a strong influence on the herbicide behavior. These soil attributes, combined with the herbicide's physicochemical characteristics and edaphoclimatic factors, control the herbicide efficacy, residual activity (Christoffoleti et al. 2008) and their impact on non-target organisms (Nguyen et al. 2016).

A research developed in Brazilian Savanna soils by Pacheco (2017) demonstrated that soil texture is not correlated with the herbicide efficacy of sulfentrazone, oxyfluorfen, diclosulan and clomazone, and that the dose of some herbicides can be greatly reduced in some soil types. Usually, the $\mathrm{pH}$, clay content and organic matter are the main soil attributes associated with the herbicide behavior on the soil (Passos et al. 2013, Freitas et al. 2014, Faustino et al. 2015, Braga et al. 2016). However, studies using correlation analyses to estimate the relationship between these attributes and herbicide sorption, efficacy or residual activity are uncommon, and those using Brazilian Savanna soils are even scarcer. In this region, there are large amounts of $\mathrm{Fe}$ and $\mathrm{Al}$ oxides in the clay fraction, associated with relatively high anion exchange capacity, low cation exchange capacity, low bases saturation and organic matter, which may affect the herbicide behavior and, therefore, its efficacy and residual activity. Alves et al. (2004) found a negative correlation of dry mass reduction percentage with the $\mathrm{Al}$ and $\mathrm{Fe}$ oxides content in the soil, indicating that the sulfentrazone may act very differently in Brazilian Savanna soils, since the amount of oxides is usually high.

Sulfentrazone $N$-[2,4-dichloro-5-[4(difluoromethyl)-3-methyl-5-oxo-1,2,4-triazol-1yl]phenyl]methanesulfonamide is one of the preemergent herbicides most used in Brazil, mainly in soybean and sugarcane crops (Rodrigues \& Almeida 2018). It is from the imidazolinones group, inhibits the protoporphyrinogen oxidase enzyme (PROTOX) and, as a consequence, the chlorophyll synthase. Sulfentrazone has a $\mathrm{pKa}$ of 6.56 , acts as a weak acid and has an average half-life dissipation $\left(t \frac{1}{2}\right)$ of 150 days after application (DAA), being also reported a variation ranging from 121 to 302 DAA (Shaner 2012). Its solubility is affected by the soil $\mathrm{pH}$, being reported values ranging from $110 \mathrm{~g} \mathrm{~L}^{-1}$ at $\mathrm{pH} 6.0$ to $1,600 \mathrm{~g} \mathrm{~L}^{-1}$ at $\mathrm{pH} 7.5$, with estimated Kow of 9.8 and Koc of 43.0 (Shaner 2012).

Changes in edaphoclimatic conditions may result in changes in the herbicide behavior and, therefore, in its efficacy, residual activity and impact on non-target organisms. Studies evaluating the residual activity of pre-emergent herbicides and their impacts on soil microorganisms are uncommon and, to the best of our knowledge, there are no researches with some typical Brazilian Savanna soils, like soils with acric attributes (soils with predominance of positive or no charges in the clay fraction). Thus, the present study aimed to evaluate the residual activity of the sulfentrazone herbicide and its impacts on microbiological parameters of Brazilian Savanna soils, as well as to identify the soil attributes that can be used to predict the sulfentrazone residual activity in these soils.

\section{MATERIAL AND METHODS}

The experiment was carried out under greenhouse conditions ( $16^{\circ} 35^{\prime} 12^{\prime \prime} \mathrm{S}$ and $\left.49^{\circ} 21^{\prime} 14^{\prime \prime} \mathrm{W}\right)$, between September and December 2019. The experimental design was completely randomized, in a $6 \times 5$ factorial scheme, with 4 replications. The evaluated factors were 5 soil types [Latossolo Vermelho Ácrico - LVw (Rhodic Acrustox); Neossolo Quartzarênico Órtico - Rqo (Typic Quartzpsamment); Latossolo Vermelho Distrófico - LVd (Rhodic Haplustox); Gleissolo Melânico Distrófico - GMd (Typic Humaquepts); and Neossolo Flúvico Tb Distrófico - RYbd (Fluventic Dystrustepts), classified according to Santos et al. (2018) and USDA (1999), respectively] and six periods $(0,15,30,45,60$ and 90 days after herbicide application - DAA). Additionally, four replications of the control, without herbicide application, were carried out for each soil, in each period. A third factor was included in the experimental design just for microbiological parameters. Regarding dry mass reduction and phytotoxicity data, control pots were used to calculate the percentage of dry mass reduction related to the control.

Each pot was filled with $0.2 \mathrm{dm}^{3}$ of soil, from the $0.00-0.20 \mathrm{~m}$ depth. The chemical characterization and texture of each soil type were assessed according to Andrade et al. (2001), and are described in Tables 1 and 2, respectively. The mineralogical 
Table 1. Chemical characterization of Brazilian Savanna soils.

\begin{tabular}{|c|c|c|c|c|c|c|c|c|c|c|c|c|}
\hline Soil type & $\begin{array}{c}\mathrm{pH} \\
\mathrm{CaCl}_{2}\end{array}$ & $\Delta \mathrm{pH}$ & $\begin{array}{c}\mathrm{OM} \\
\mathrm{g} \mathrm{kg}^{1}\end{array}$ & $\begin{array}{c}\mathrm{P} \\
\mathrm{m} \\
\end{array}$ & $\begin{array}{c}\mathrm{S} \\
\mathrm{m}^{3} \\
\end{array}$ & $\mathrm{~K}$ & $\mathrm{Ca}$ & $\begin{array}{l}\mathrm{Mg} \\
-\mathrm{cm}\end{array}$ & $\begin{array}{c}\mathrm{Al} \\
\mathrm{m}^{3}-\end{array}$ & $\mathrm{T}$ & $\mathrm{t}$ & $\begin{array}{l}\mathrm{V} \\
\% \\
\end{array}$ \\
\hline RQo & 4.3 & -0.6 & 9.0 & 3.4 & 5.0 & 0.06 & 0.4 & 0.2 & 0.3 & 2.99 & 1.0 & 22.94 \\
\hline RYbd & 4.3 & -0.4 & 29.0 & 2.4 & 7.1 & 0.04 & 0.3 & 0.2 & 0.5 & 4.78 & 1.1 & 12.11 \\
\hline GMd & 4.4 & -0.6 & 32.0 & 34.4 & 34.4 & 0.15 & 2.2 & 1.4 & 0.5 & 9.35 & 4.4 & 41.22 \\
\hline LVw & 5.6 & -0.6 & 23.0 & 1.2 & 2.8 & 0.05 & 0.3 & 0.2 & 0.0 & 2.57 & 0.6 & 22.07 \\
\hline LVd & 4.6 & -0.4 & 25.0 & 0.8 & 3.4 & 0.06 & 0.3 & 0.2 & 0.4 & 6.39 & 1.0 & 9.17 \\
\hline
\end{tabular}

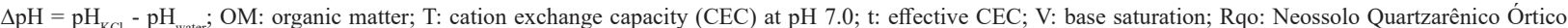
(Typic Quartzpsamment); RYbd: Neossolo Flúvico Tb Distrófico (Fluventic Dystrustepts); GMd: Gleissolo Melânico Distrófico (Typic Humaquepts); LVw: Latossolo Vermelho Ácrico (Rhodic Acrustox); LVd: Latossolo Vermelho Distrófico (Rhodic Haplustox).

Table 2. Granulometric composition $\left(\mathrm{g} \mathrm{kg}^{-1}\right)$ and clay mineralogy of Brazilian Savanna soils.

\begin{tabular}{lrrll}
\hline \multicolumn{1}{c}{ Soil type } & Clay & Silt & Sand & Clay mineralogy \\
\hline RQo & 90 & 40 & 870 & Caulinite, gibsite and VHI \\
RYbd & 110 & 50 & 840 & Caulinite, VHI and gibsite \\
GMd & 320 & 90 & 590 & Caulinite, VHI and gibsite \\
LVw & 440 & 450 & Gibsite, caulinite and VHI \\
LVd & 500 & 110 & 390 & Gibsite, caulinite and VHI \\
\hline
\end{tabular}

VHI: vermiculite hydroxy interlayered; Rqo: Neossolo Quartzarênico Órtico (Typic Quartzpsamment); RYbd: Neossolo Flúvico Tb Distrófico (Fluventic Dystrustepts); GMd: Gleissolo Melânico Distrófico (Typic Humaquepts); LVw: Latossolo Vermelho Ácrico (Rhodic Acrustox); LVd: Latossolo Vermelho Distrófico (Rhodic Haplustox).

characterization was determined by x-ray diffraction (Moore \& Reynolds 1997).

Prior to the herbicide application, the soil moisture was raised to $60 \%$ of the its maximum water retention capacity and maintained during all the experiment by daily weighing,

The sulfentrazone herbicide was applied using the commercial formulation Boral ${ }^{\circledR} 500 \mathrm{SC}, \mathrm{FMC}$ (500 g a.i. $\left.\mathrm{L}^{-1}\right)$, at the recommended rate of $1.2 \mathrm{~L} \mathrm{ha}^{-1}$. The herbicide application was performed using a back-pack sprayer pressurized with $\mathrm{CO}_{2}$, equipped with a 2 -m-wide boom and four flat-fan nozzles (XR 110.02).

In each evaluating time $(0,15,30,45,60$ and 90 DAA), ten seeds of signal grass (Urochloa decumbens Stapf.) were sown per pot, at a depth of $0.05 \mathrm{~m}$, at 28 days after sowing. The herbicide phytotoxicity to $U$. decumbens was quantified using a diagrammatic scale ranging from 0 to 100 , with zero corresponding to absence of symptoms and 100 to the death of all plants in each plot. Then, the aboveground part was cut, near to the soil surface, and air forced dried at $65^{\circ} \mathrm{C}$, for $72 \mathrm{~h}$, to dry mass determination.

The microbial biomass carbon (MBC) was determined according to Vance et al. (1987), with some modification proposed by Knupp \& Ferreira (2011). The respiration rate (RR) was quantified at 48-h intervals, using an 8-day laboratory incubation
(Silva et al. 2007), and presented as an average per hour. The metabolic coefficient $\left(q \mathrm{CO}_{2}\right)$ was calculated as the $\mathrm{RR} / \mathrm{MBC}$ ratio.

The dry mass data were transformed into dry mass reduction percentage (DMR\%) related to the control pots (without herbicide application). It was calculated using the following equation: $\mathrm{DMR} \%=\left[\left(\right.\right.$ average of $\left.\mathrm{DM}_{\text {control }}-\mathrm{DM}_{\text {treatment }}\right) /$ average of $\left.\mathrm{DM}_{\text {control }}\right] * 100$, where: average $\mathrm{DM}_{\text {control }}$ is the average of dry mass in control pots (without herbicide application), in each soil and period; and $\mathrm{MS}_{\text {treatment }}$ the dry mass obtained in each replication.

A two-way statistical analysis was performed and, when the F test was significant, the Tukey test $(p=0.05)$ was used to compare qualitative treatments, i.e., soil types or herbicide use (this third factor was applied for microbiological parameters only). Regression analyses were used to describe how the evaluated parameters behaved over time. The F test significance $(\mathrm{p}<0.05)$, the predict and adjusted $\mathrm{R}^{2}$ (higher than 0.8) and the residual plots independence (including the Durbin-Watson test to verify the correlation between adjacent residuals) were used to choose the model with the best fit. If more than one model matched these criteria, the model with the lowest number of parameters was chosen.

Following these criteria, the data for DMR\% and phytotoxicity were adjusted to the Seefeldt et 
al. (1995) model or the linear model. These models were used to calculate the time (in days) that the sulfentrazone was able to guarantee 80,50 and $20 \%$ of DMR $\%$ in each soil type. The choice of these DMR\% values is justified as it follows: $80 \%$ minimum DMR $\%$ necessary to consider the herbicide as efficient; $50 \%$ - may be related with half-life dissipation (period in days necessary to reduce in $50 \%$ the molecules activity in the soil); $20 \%$ - may indicate the period (in days) that the herbicide is able to promote symptoms of injuries in plants.

Pearson's correlations were used to identify possible relationships between herbicide efficacy over time and texture or soil chemical attributes of Brazilian Savanna soils.

\section{RESULTS AND DISCUSSION}

The dry mass reduction percentage (DMR\%) of Urochloa decumbens following the sulfentrazone application was greatly affected by the soil type and the period elapsed after the herbicide application (DAA) prior to sowing. However, there was no interaction between these factors (Table 3). A higher DMR\% was observed for LVd, when compared to RQo and GMd, with the latter showing the lowest DMR\% average. As expected, there was a reduction in the DMR\% over time (Figure 1).

The log logistic model, with three parameters, showed a better adjustment for the Oxisols (LVd and $\mathrm{LVw}$ ), with $\mathrm{R}^{2}$ values higher than 0.95 (Table 4). For the Entisols (RQo and RYbd), even though the log logistic model showed a good fit (data not shown), the DMR $\%$ over time was better described by a linear model, since it showed a higher $\mathrm{R}^{2}$ and had a lower number of parameters. The Oxisols had a higher clay content than the Entisols, which have a sandy texture and may reduce the number of sites to herbicide retention in the soil, facilitating its leaching and favoring a linear reduction of the DMR\% over time, since the DMR\% is dependent on the herbicide's molecules availability on the soil.

Regarding the GMd, no model fitted well to the DMR\% in this soil (Table 4), and the DMR\% was low even at 0 DAA, suggesting that the sulfentrazone had a lower efficacy in weed control in this soil (Figure 1), what was observed by Pacheco (2017) as well. Sulfentrazone has a low solubility at $\mathrm{pH}$ values lower than 5.0; moreover, it has a high Kow, being expected a lower efficacy of this herbicide in soils with large amounts of organic matter, such as the GMd and RYbd (Santos et al. 2018). However, the GMd was the only one showing a low DMR\% from

Table 3. Dry mass reduction (percentage related to control without herbicide) and phytotoxicity induced by sulfentrazone to Urochloa decumbens, after the herbicide application to Brazilian Savanna soils.

\begin{tabular}{ccc}
\hline Soil type & Dry mass reduction (\%) & Phytotoxicity (\%) \\
\hline RQo & $54.91 \mathrm{~b}$ & $56.00 \mathrm{a}$ \\
$\mathrm{RYbd}$ & $65.70 \mathrm{ab}$ & $56.00 \mathrm{a}$ \\
$\mathrm{GMd}$ & $25.00 \mathrm{c}$ & $35.90 \mathrm{~b}$ \\
$\mathrm{LVw}$ & $65.10 \mathrm{ab}$ & $69.80 \mathrm{a}$ \\
$\mathrm{LVd}$ & $75.30 \mathrm{a}$ & $70.80 \mathrm{a}$ \\
\hline $\mathrm{CV}(\%)$ & 34.00 & 32.00 \\
\hline $\mathrm{F}_{\text {soil }}$ & $23.23^{* *}$ & $13.51^{* *}$ \\
\hline $\mathrm{F}_{\mathrm{DAA}}$ & $16.77^{* *}$ & $17.66^{* *}$ \\
\hline $\mathrm{F}_{\text {soil x DAA }}$ & $1.27^{\text {ns }}$ & $1.52^{\text {ns }}$ \\
\hline ** and ns: significant at 1 \% and not significant, respectively, by the F test. \\
Averages followed by the same letter in the columns did not differ by the Tukey \\
test (p < 0.01). Rqo: Neossolo Quartzarênico Órtico (Typic Quartzpsamment); \\
RYbd: Neossolo Flúvico Tb Distrófico (Fluventic Dystrustepts); GMd: Gleissolo \\
Melânico Distrófico (Typic Humaquepts); LVw: Latossolo Vermelho Ácrico \\
(Rhodic Acrustox); LVd: Latossolo Vermelho Distrófico (Rhodic Haplustox); \\
DAA: days after herbicide application.
\end{tabular}

Table 4. Regression models used to predict the time (in days) that the sulfentrazone guaranteed 80,50 or $20 \%$ of dry mass reduction (percentage related to the control without herbicide) in Urochloa decumbens, after the herbicide application in Brazilian Savanna soils.

\begin{tabular}{llrrrr}
\hline \multirow{2}{*}{ Soil type } & \multicolumn{1}{c}{ Model } & \multirow{2}{*}{$\mathrm{R}^{2}$} & \multicolumn{3}{c}{ Estimate residual effect (days) } \\
\cline { 4 - 6 } & & & DMR80\% & DMR50\% & DMR20\% \\
\hline RQo & $\mathrm{y}=89.1259-0.5847 \mathrm{x}$ & $0.80^{*}$ & 9.4 & 46.0 & 82.6 \\
RYbd & $\mathrm{y}=87.7096-0.8199 \mathrm{x}$ & $0.95^{* *}$ & 15.6 & 66.9 & 118.2 \\
GMd & Without adjustment & - & 0.0 & 0.0 & - \\
LVw & $\mathrm{y}=85.7556 /\left[1+(\mathrm{x} / 67.7145)^{2.8224}\right]$ & $0.98^{* *}$ & 21.4 & 60.1 & 114.1 \\
LVd & $\mathrm{y}=92.8835 /\left[1+(\mathrm{x} / 85.2589)^{2.2475}\right]$ & $0.95^{* *}$ & 37.8 & 79.6 & 151.6 \\
\hline
\end{tabular}

* and **: significant at $1 \%$ and $5 \%$, respectively, by the $\mathrm{F}$ test. y: dry mass reduction (DMR\%); $\mathrm{x}$ : time (in days) that the sulfentrazone guaranteed 80,50 or $20 \%$ for DMR. Rqo: Neossolo Quartzarênico Órtico (Typic Quartzpsamment); RYbd: Neossolo Flúvico Tb Distrófico (Fluventic Dystrustepts); GMd: Gleissolo Melânico Distrófico (Typic Humaquepts); LVw: Latossolo Vermelho Ácrico (Rhodic Acrustox); LVd: Latossolo Vermelho Distrófico (Rhodic Haplustox). 
0 DAA. This soil differed from the others, since it has high rates of sulfate, phosphate and cations, as well as calcium and magnesium, which may affect the sulfentrazone activity.

The time (in days) in which the sulfentrazone was able to reduce in $80 \%$ the $U$. decumbens dry mass ranged from 0.0 (GMd), followed by 9.4 (RQo), with the highest value being observed for the LVd (37.8) (Table 4). At 90 DAA, only the RQo showed
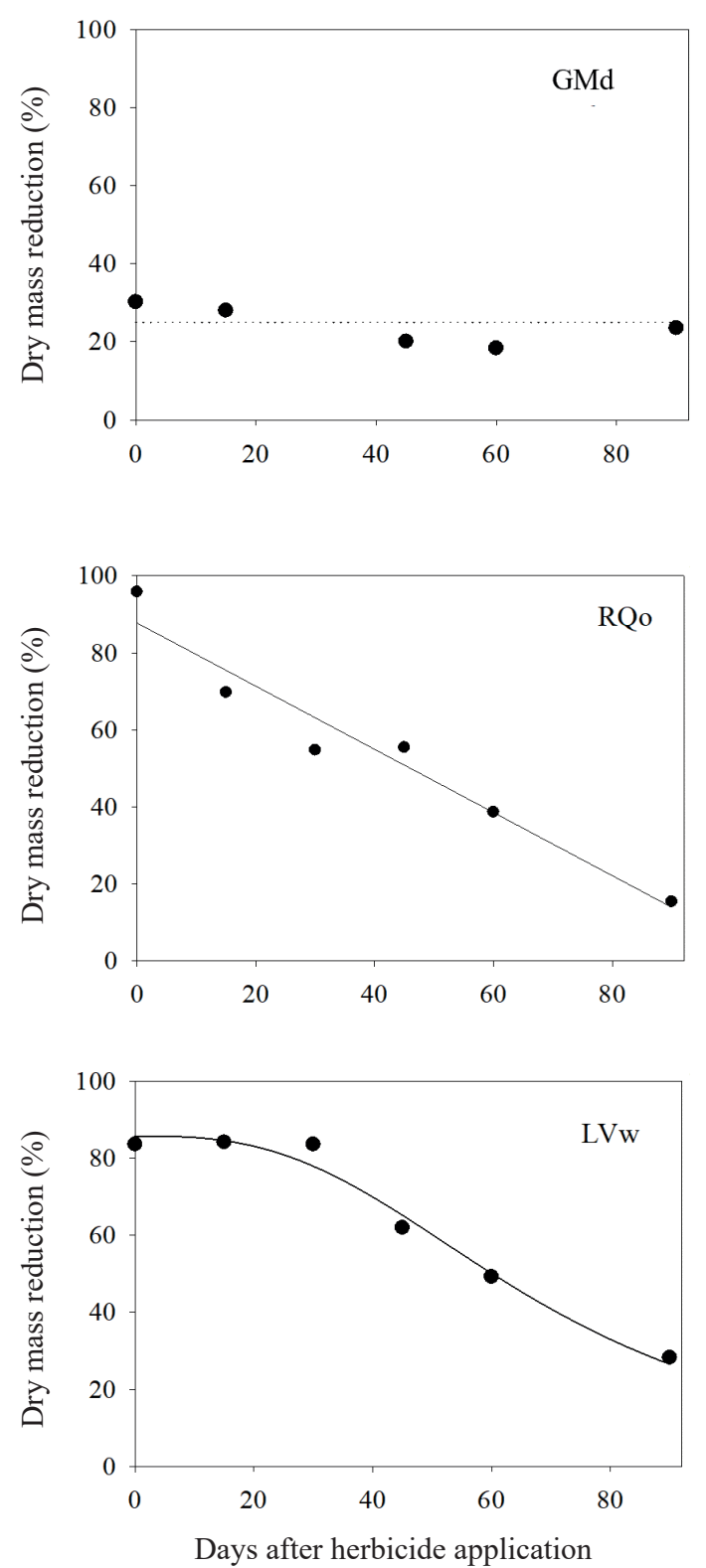

DMR \% lower than $20 \%$, with the LVd and RYbd showing a DMR\% higher than $45 \%$ (Figure 1 ).

Since sulfentrazone may be toxic to some crops, it is important to consider for how long it will remain active in the soil, aiming to avoid phytotoxic effects to crops in succession, in areas where this herbicide was applied. Sulfentrazone has a relatively high persistence on the soil, with an average halflife dissipation $\left(\mathrm{t}^{1} / 2\right)$ of 150 days, being reported a variation ranging from 121 to 302 days (Shaner 2012). The edaphoclimatic conditions greatly affect the herbicide persistence. Brum et al. (2013) found a $t^{1 / 2}$ ranging from 34 to 116 days, according to the soil type (Oxisols or Entisols), soil moisture (50 and $80 \%$ of moisture at the field capacity) and temperature $\left(30\right.$ and $\left.40{ }^{\circ} \mathrm{C}\right)$. Similarly, we found that the range from 46 to 79.6 days was the period required by the sulfentrazone to promote $50 \%$ of DMR in $U$. decumbens (Table 4). Other studies reported a $\mathrm{t}^{1} / 2$ higher than 150 days; however, in dry soil conditions (Lourenço et al. 2015), or with
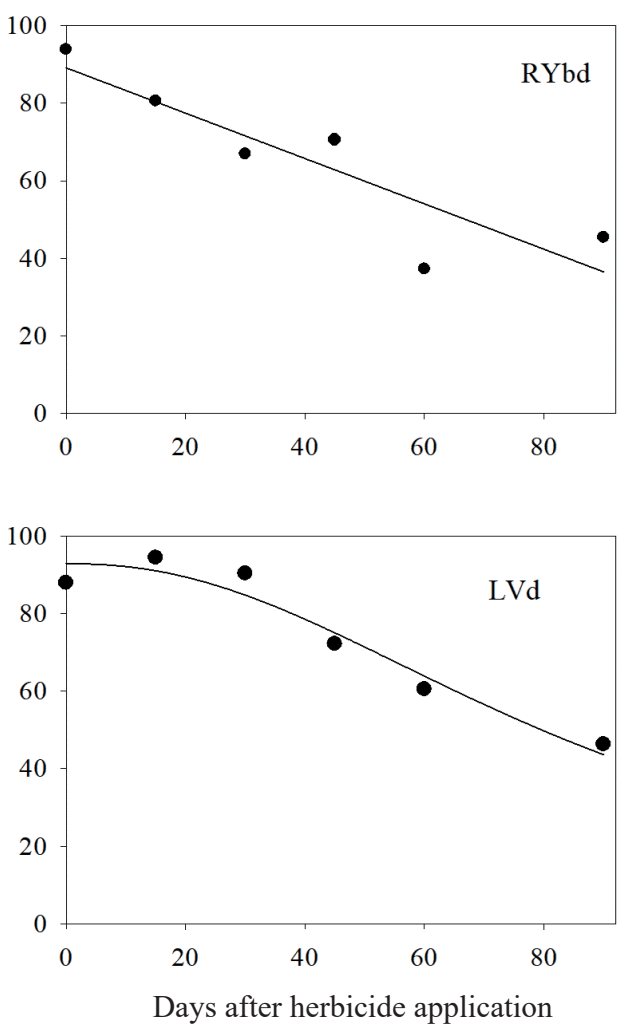

Figure 1. Dry mass reduction (percentage related to the control without herbicide) over time induced by sulfentrazone to Urochloa decumbens, after the herbicide application in Brazilian Savanna soils. Rqo: Neossolo Quartzarênico Órtico (Typic Quartzpsamment); RYbd: Neossolo Flúvico Tb Distrófico (Fluventic Dystrustepts); GMd: Gleissolo Melânico Distrófico (Typic Humaquepts); LVw: Latossolo Vermelho Ácrico (Rhodic Acrustox); LVd: Latossolo Vermelho Distrófico (Rhodic Haplustox). 
soil temperatures lower than $30^{\circ} \mathrm{C}$ (Martinez et al. 2008).

As expected, the phytotoxicity of sulfentrazone to $U$. decumbens plants was affected by the soil type (Table 3), with the GMd showing the lowest phytotoxicity, when compared to the others, following the same pattern observed for the DMR\%.
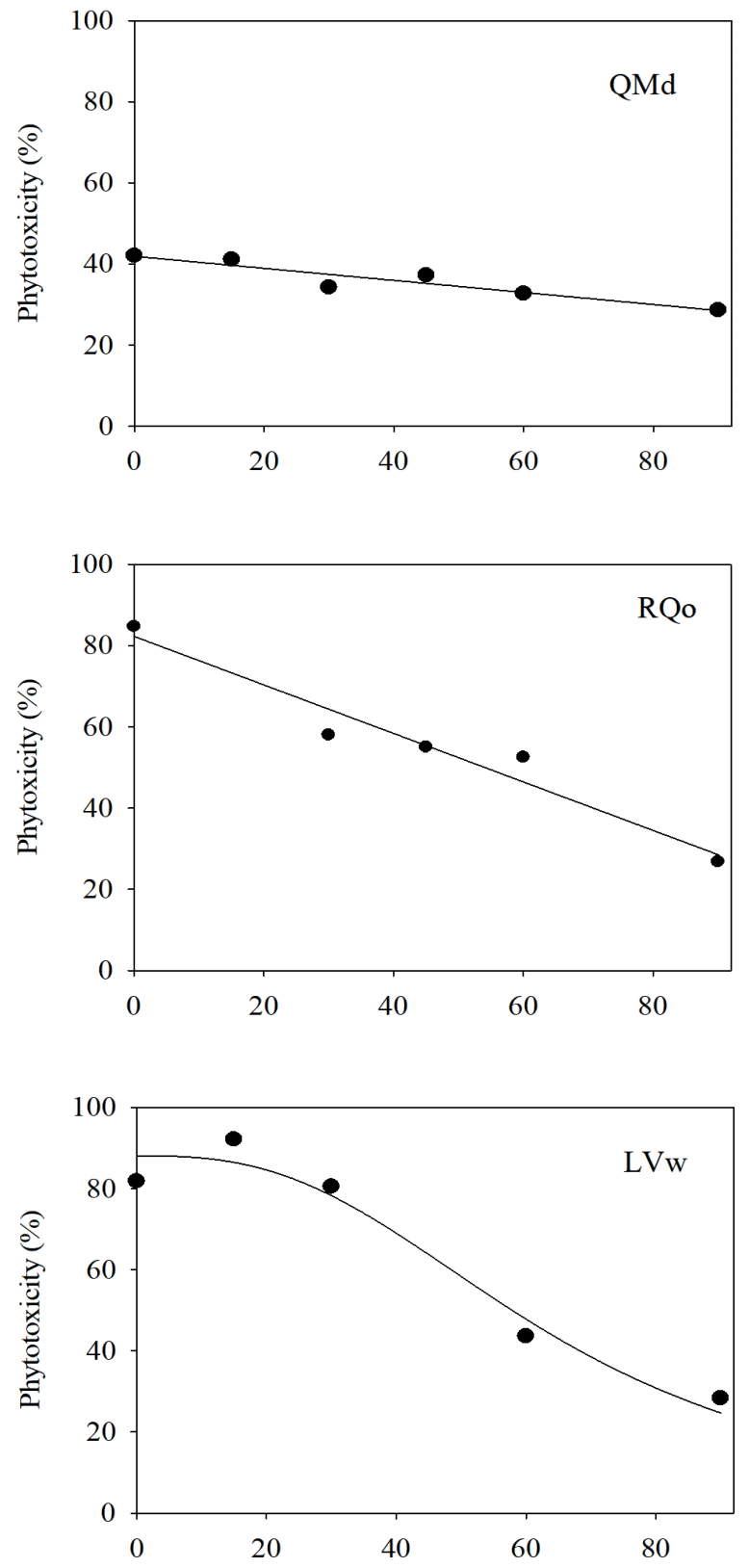

Days after herbicide application
The number of days after the herbicide application also affected it; however, there was no interaction between these factors. Similarly, for the DMR \%, the phytotoxicity was better described by a log-logistic model in the LVd and LVw, while a linear model better described the phytotoxicity in the RQo and RYbd. The GMd also showed an adequate adjustment to the linear model (Figure 2).

The sulfentrazone residual activity, measured by the DMR \% over time, was not correlated with the clay content (not significant by the Pearson's test), showing Pearson's coefficients $(\mathrm{r})$ of 0.21 (0 DAA); -0.16 (15 DAA); -0.38 (30 DAA); -0.03 (45 DAA); -0.31 (60 DAA); and -0.21 (90 DAA). In the same way, the $\mathrm{pH}$ was not correlated with the $\mathrm{DMR} \%$, showing $r$ values of 0.11 (0 DAA); 0.27 (15 DAA); 0.42 (30 DAA); 0.11 (45 DAA); 0.27 (60 DAA); and 0.04 (90 DAA), all of them being not significant. Similar results were found by Alves et al. (2004), who
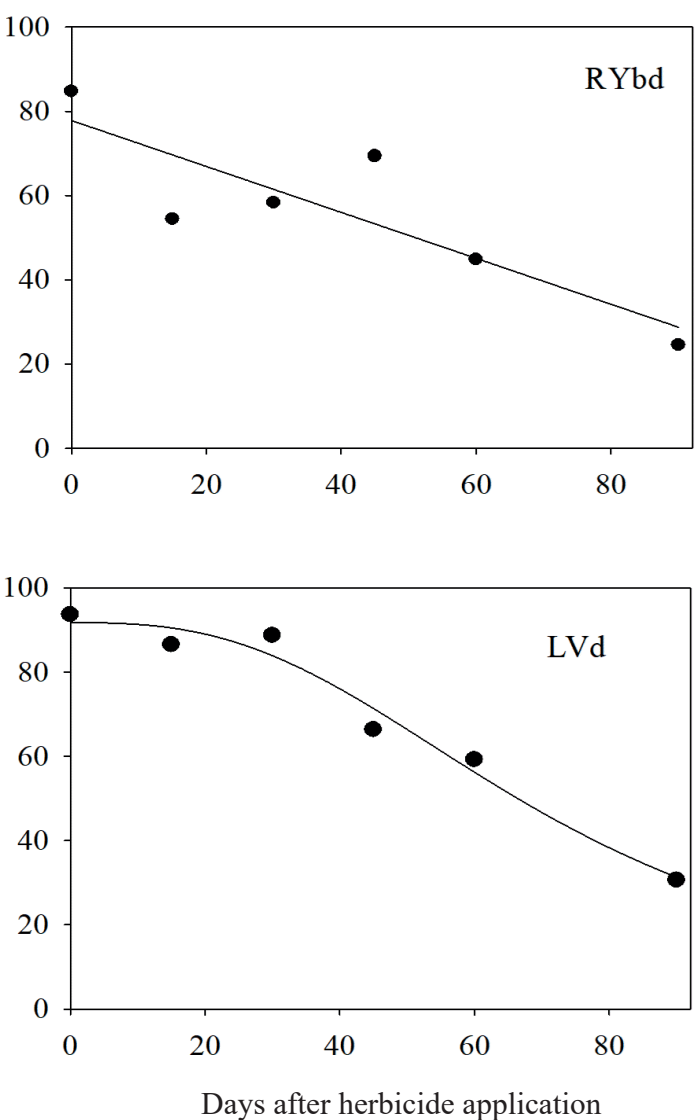

Figure 2. Phytotoxicity over time induced by sulfentrazone to Urochloa decumbens, after the herbicide application in Brazilian Savanna soils. Rqo: Neossolo Quartzarênico Órtico (Typic Quartzpsamment); RYbd: Neossolo Flúvico Tb Distrófico (Fluventic Dystrustepts); GMd: Gleissolo Melânico Distrófico (Typic Humaquepts); LVw: Latossolo Vermelho Ácrico (Rhodic Acrustox); LVd: Latossolo Vermelho Distrófico (Rhodic Haplustox). 
did not find a correlation for the clay content or $\mathrm{pH}$ with the DMR\% of Cyperus Rotundus in 6 soil types, at 0 DAA; and by Kerr et al. (2004), who showed no correlation between the $\mathrm{pH}$ and the sulfentrazone phytotoxic potential at 0 DAA. The organic matter content showed a moderate $(-0.51)$ and significant correlation with the DMR\% only at 0 DAA. No correlation was observed between organic matter and $\mathrm{DMR} \%$ after this time, with $\mathrm{r}$ value of 0.22 (15 DAA); -0.10 (30 DAA); -0.17 (45 DAA); -0.17 (60 DAA); and -0.37 (90 DAA).

Freitas et al. (2014) also observed that the clay content is not an adequate parameter to predict sulfentrazone sorption. These authors evaluated the herbicide sorption in five soil types, and the one with the highest clay content, an Oxisol (LVA), did not show a high sulfentrazone sorption, even with a high organic matter content. However, they observed that a sandy soil had a lower herbicide retention.

Sulfentrazone acts as a weak acid, with $\mathrm{pKa}$ value of 6.56 (Grey et al. 2009). Therefore, soils with pH lower than 5.5 will have $90 \%$ of the herbicide's molecules in molecular form, i.e., without ionization. Considering the soil types used in this study, the $\mathrm{LVw}$ was the only one with $\mathrm{pH}$ value near 5.5, with the others showing $\mathrm{pH}$ values even lower, indicating that the sulfentrazone was in the molecular form in these soils. However, Grey et al. (2009) found that, even for $\mathrm{pH}$ values lower than the $\mathrm{pKa}$, sulfentrazone molecules may show some parts positively and others negatively charged, featuring zwitterionic properties, even though with the sum of charges being zero. This fact indicates that sulfentrazone can be retained in both the positive and negative charges available in the surface of colloids. The DMR\% showed a high negative correlation with the effective cation exchange capacity - CEC (CEC in the current soil $\mathrm{pH}$ value) up to $60 \mathrm{DAA}$ and with the potential CEC (CEC at pH 7.0) up to 15 DAA (Figure 3). Similar results were observed by Kerr et al. (2004), who found a higher sulfentrazone phytotoxicity when the CEC was reduced, suggesting a higher availability of the herbicide's molecules in the solution when the CEC was lower.

Since sulfentrazone can behave as a zwitterionic molecule, it can interact with both positive and negative groups/ions present in the surface of colloids. Grey et al. (2009) evaluated the herbicide sorption in $\mathrm{Ca}^{2+}, \mathrm{K}^{+}$or $\mathrm{Na}^{+}$saturated resin and observed an increase in the herbicide sorption with

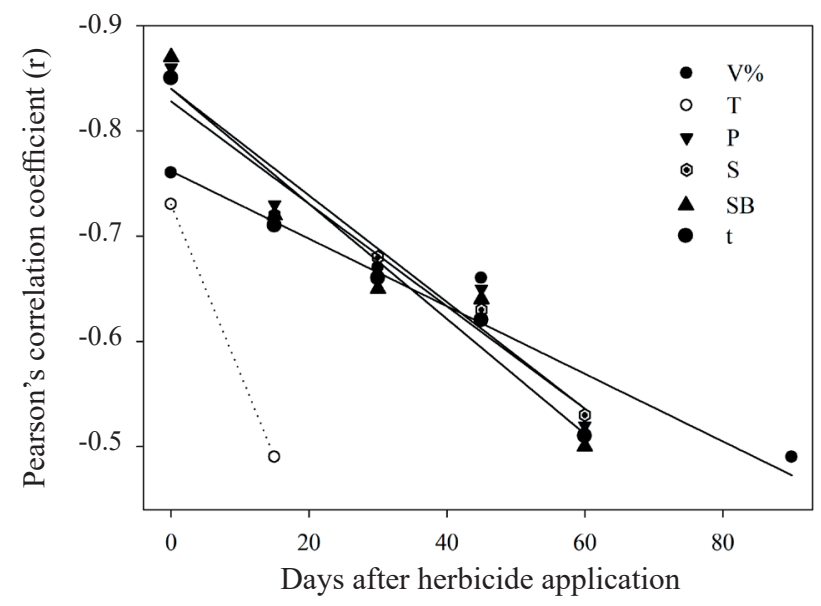

Figure 3. Pearson's correlation coefficient over time between soil chemical attributes and dry mass reduction (percentage related to the control without herbicide application). V\%: base saturation; T: cation exchange capacity (CEC) at pH 7.0; P: phosphorus; S: sulfur; SB: sum of bases; t: effective CEC.

the increase of these ions in the resin, evidencing that the sulfentrazone sorption is also ion-dependent. Similarly, we found a high negative correlation for the DMR $\%$ with the sum of bases $(\mathrm{Ca}+\mathrm{Mg}+\mathrm{K})$ and bases saturation (V\%) (Figure 3), with the V\% being the only soil attribute correlated with the DMR\% up to $90 \mathrm{DAA}$, even though showing a moderate correlation from 30 DAA (Figure 3).

A high negative correlation up to $30 \mathrm{DAA}$ was also observed between the DMR\% and ions with a negative charge in the soil, like phosphorus (P) and sulfur (S) (Figure 3). After that, a moderate correlation was observed up to $60 \mathrm{DAA}$. Interestingly, the $\mathrm{P}, \mathrm{S}$, sum of bases and effective CEC $(\mathrm{t})$ behaved very similarly (Figure 3 ), showing a high correlation with the DMR\% at 0 and $15 \mathrm{DAA}$, a moderate correlation up to $60 \mathrm{DAA}$, and no correlation at 90 DAA. These results suggest that, as demonstrated by Grey et al. (2009), sulfentrazone may interact with both positive and negative charges, changing its efficacy. However, these soil attributes are not able to predict the herbicide residual effect (a significant correlation was not observed at 90 DAA).

The correlation analyses results are useful to explain why the $\mathrm{DMR} \%$ and the phytotoxicity were lower in the GMd than in the other soils, even at 0 DAA. This soil showed the highest $\mathrm{V} \%, \mathrm{SB}, \mathrm{t}$, phosphate and sulfate values, greatly differing from the others. Moreover, the sulfentrazone residual 
activity, measured by the DMR\% and phytotoxicity, was lower in the GMd and higher in the LVd, when compared with the other soils. These soils showed, respectively, the highest and lowest V\% values. In fact, comparing the time (in days) that the sulfentrazone was able to reduce in 20,50 or $80 \%$ the $B$. decumbens dry mass in the soils, the sequence was $\mathrm{LVd}>\mathrm{RYbd}>\mathrm{LVw}>\mathrm{RQo}>\mathrm{GMd}$, exactly the opposite of the $\mathrm{V} \%$, which showed the same sequence, but in the reverse order.

The sulfentrazone application in the Brazilian Savanna soils used in this experiment did not affect the microbial biomass carbon (MBC) and the metabolic coefficient $\left(q \mathrm{CO}_{2}\right)$ (Table 5). However, these parameters varied with the soil type. The GMd and LVd showed a higher $\mathrm{MBC}$ value, when compared with the LVw and RQo, while the $q \mathrm{CO}_{2}$ was higher in the LVw than in the GMd; however, these soils did not differ from the others (Table 5). Since the soils were collected at native vegetation areas, these differences may be related to the soil attributes. The evaluation time (DAA) affected the MBC, although it did not adjust to any model. There was no interaction effect among these factors for $\mathrm{MBC}$ and $q \mathrm{CO}_{2}$ (Table 5).

Results in the literature show that the sulfentrazone effect on $\mathrm{MBC}$ and $q \mathrm{CO}_{2}$ may have

Table 5. Microbial biomass carbon (MBC), respiration rates (RR) and metabolic coefficient $\left(q \mathrm{CO}_{2}\right)$ following the sulfentrazone application in Brazilian Savanna soils.

\begin{tabular}{|c|c|c|c|}
\hline \multirow[b]{2}{*}{ Soil type } & $\mathrm{MBC}$ & RR & \multirow[b]{2}{*}{$q \mathrm{CO}_{2}$} \\
\hline & $\mathrm{C}\left(\mu \mathrm{g} \mathrm{g}^{-1}\right.$ of soil $)$ & $\begin{array}{c}\mathrm{CO}_{2} \mu \mathrm{g} \mathrm{g}^{-1} \text { of } \\
\text { soil day } \\
\end{array}$ & \\
\hline RQo & $143.00 \mathrm{c}$ & 12.20 & $0.09 \mathrm{ab}$ \\
\hline RYbd & $216.30 \mathrm{bc}$ & 13.40 & $0.06 \mathrm{ab}$ \\
\hline GMd & $383.50 \mathrm{a}$ & 12.70 & $0.03 \mathrm{~b}$ \\
\hline $\mathrm{LVw}$ & $165.60 \mathrm{c}$ & 12.80 & $0.11 \mathrm{a}$ \\
\hline LVd & $288.00 \mathrm{ab}$ & 13.10 & $0.05 \mathrm{ab}$ \\
\hline CV $(\%)$ & 64.00 & 15.70 & 112.60 \\
\hline $\mathrm{F}_{\text {soil }}$ & $14.73 * *$ & $1.82^{\mathrm{ns}}$ & $3.76^{* *}$ \\
\hline$F_{\text {herbicide }}$ & $1.17^{\mathrm{ns}}$ & $49.30 * *$ & $0.18^{\text {ns }}$ \\
\hline $\mathrm{F}_{\mathrm{DAA}}$ & $3.38 * *$ & $150.86^{* *}$ & $1.40^{\mathrm{ns}}$ \\
\hline $\mathrm{F}_{\text {soil } x \text { herbicide }}$ & $0.76^{\mathrm{ns}}$ & $1.14^{\mathrm{ns}}$ & $1.67^{\mathrm{ns}}$ \\
\hline $\mathrm{F}_{\text {soil } \times \text { DAA }}$ & $1.24^{\mathrm{ns}}$ & $1.74 *$ & $1.19^{\mathrm{ns}}$ \\
\hline$F_{\text {herbicide } x \text { DAA }}$ & $2.18^{\mathrm{ns}}$ & $4.09 * *$ & $0.54^{\mathrm{ns}}$ \\
\hline $\mathrm{F}_{\text {soil } x \text { herbicide } x \text { DAA }}$ & $0.68^{\text {ns }}$ & $0.64^{\mathrm{ns}}$ & $1.01^{\mathrm{ns}}$ \\
\hline \multicolumn{4}{|c|}{ 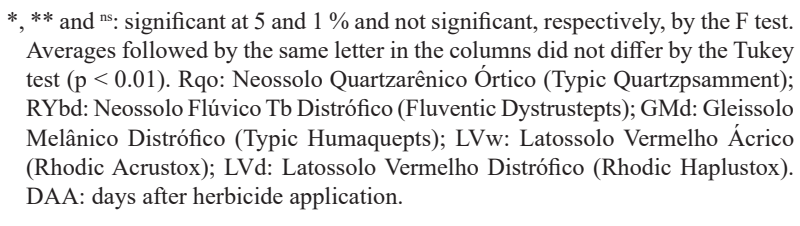 } \\
\hline
\end{tabular}

contrasting results. Some studies found a negative impact of this herbicide on $\mathrm{MBC}$ or $q \mathrm{CO}_{2}$ (Silva et al. 2014, Madalão et al. 2016), according to the soil type; while Tironi et al. (2009) did not find any effect of this herbicide on MBC. Many factors may affect the herbicide behavior on the soil, with the soil attributes being one of the most important. Even though these studies have used soil types similar to those in the present study, variations in soil fertility, microorganisms communities, texture and others may greatly affect the herbicide effect on soil microorganisms (Nguyen et al. 2016).

The respiration rates were not affected by the soil type; however, the herbicide application and DAA affected them, with a significant interaction between these two factors (Table 5). A negative impact of sulfentrazone on respiration rates was observed from 45 to 90 DAA (Figure 4). Similar results were obtained by Vivian et al. (2006) and Madalão et al. (2016), who also observed a negative impact of this herbicide on respiration rates.

The soil microbiological parameters evaluated in this study are quantitative. The microbial biomass carbon measures the impact of management strategies such as herbicide application on microorganisms abundance, while the respiration rates measure their activity. However, they cannot be used to evaluate the herbicide effect on soil diversity or in specific groups, what requires more qualitative analyses. There are few studies available in the literature evaluating qualitative effects of sulfentrazone on

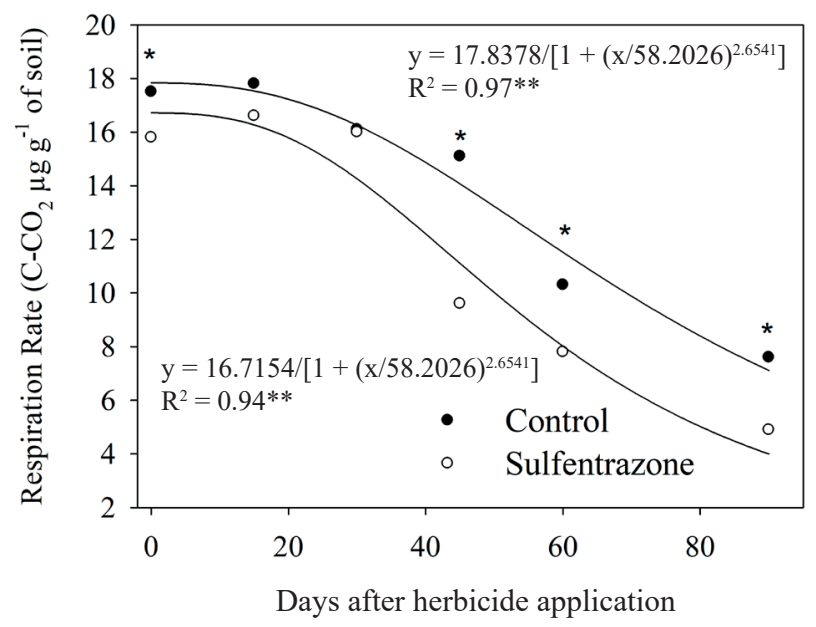

Figure 4. Soil respiration rate over time following the sulfentrazone application in Brazilian Savanna soils. ** and *: significant at 1 and $5 \%$, respectively, by the $\mathrm{F}$ test. 
soil microorganisms or processes related to them. Daugrois et al. (2005) observed some changes in microbial communities and Vieira et al. (2007) found a reduction in nitrogen biological fixation. Future research evaluating the sulfentrazone impact on soil diversity is important to have a better understanding of the impact of this herbicide on the soil functionality and biological quality.

\section{CONCLUSIONS}

1. The sulfentrazone residual activity is dependent of soil attributes. The time in which the herbicide can control at least $80 \%$ of Urochloa decumbens plants ranges from 0 to 38 days;

2. The bases saturation is the only soil attribute correlated with the herbicide efficacy over time in Brazilian Savanna soils, showing a moderate correlation up to 90 days after application. The $\mathrm{pH}$, organic matter and clay content do not have correlation with the herbicide efficacy over time in these soils;

3. Sulfentrazone reduces the activity of soil microorganisms in all the Brazilian Savanna soils investigated in this study, from 45 to 90 days after application. However, it does not affect the microbial biomass carbon.

\section{REFERENCES}

ALVES, P. L. C.A.; MARQUES JÚNIOR, J.; FERRAUDO, A. S. Soil attributes and efficiency of sulfentrazone on control of purple nutsedge (Cyperus rotundus L.). Scientia Agricola, v. 61, n. 3, p. 319-325, 2004.

ANDRADE, J. C.; CANTARELLA, H.; QUAGGIO, J. A. Análise química para avaliação da fertilidade de solos tropicais. Campinas: Instituto Agronômico, 2001.

BOMBARDI, L. M. Geografia do uso de agrotóxicos no Brasil e conexões com a União Europeia. São Paulo: FFLCH, 2017.

BRAGA, D. F.; FREITAS, F. C. L.; ROCHA, P. R. R.; ARAÚJO, A. G. D.; MELO, V. C. Leaching of sulfentrazone in soils from the sugarcane region in the Northeast region of Brazil. Planta Daninha, v. 34, n. 1, p. 161-169, 2016.

BRUM, C. S.; FRANCO, A. A.; SCORZA JÚNIOR, R. P. Degradação do herbicida sulfentrazone em dois solos de Mato Grosso do Sul. Revista Brasileira de Engenharia Agrícola e Ambiental, v. 17, n. 5, p. 558-564, 2013.
CHRISTOFFOLETI, P. J.; OVEJERO, R. F. L.; DAMIN, V.; CARVALHO, S. J. P. de; NICOLAI, M. Comportamento dos herbicidas aplicados ao solo na cultura da cana-deaçúcar. Piracicaba: Esalq, 2008.

DAUGROIS, J. H.; HOY, J. W.; GRIFFIN, J. L. Protoporphyrinogen oxidase inhibitor herbicide effects on pythium root rot of sugarcane, pythium species, and the soil microbial community. Phytopathology, v. 95, n. 3 , p. 220-226, 2005.

FAUSTINO, L. A.; FREITAS, M. A. M.; PASSOS, A. B. R. J.; SARAIVA, D. T.; FARIA, A. T.; SILVA, A. A.; FERREIRA, L. R. Mobilidade do sulfentrazone em solos com diferentes características físicas e químicas. Planta Daninha, v. 33, n. 4, p. 795-802, 2015.

FREITAS, M. A. M.; PASSOS, A. B. R. J.; TORRES, L. G.; MORAES, H. M. F.; FAUSTINO, L. A.; ROCHA, P. R. R.; SILVA, A. A. Sulfentrazone sorption in different types of soil by bioassays. Planta Daninha, v. 32, n. 2 , p. 385-392, 2014.

GREY, T. L.; WALKER, R. H.; WEHTJE, G. R.; ADAMS, J. Behavior of sulfentrazone in ionic exchange resins, electrophoresis gels, and cation-saturated soils. Weed Science, v. 48, n. 2, p. 239-247, 2009.

KERR, G. W.; STAHLMAN, P. W.; DILLE, J. A. Soil pH and cation exchange capacity affects sunflower tolerance to sulfentrazone. Weed Technology, v. 18, n. 2, p. 243247, 2004.

KNUPP, A. M.; FERREIRA, E. P. D. B. Eficiência da quantificação do carbono da biomassa microbiana por espectrofotometria comparada ao método titrimétrico. Revista Brasileira de Ciências Agrárias, v. 6, n. 4, p. 588595, 2011.

LOURENÇO, R. C.; CARVALHO, S. J. P. Bioindicator demonstrates high persistence of sulfentrazone in dry soil. Pesquisa Agropecuária Tropical, v. 45, n. 3, p. 326-332, 2015.

MADALÃO, J. C.; SILVA, A. A.; ORLANDO, W. A.; SARAIVA, D. T.; MELO, C. A. D.; D’ANTONINO, L. O herbicida sulfentrazone interfere na biomassa microbiana e na atividade da microbiota do solo. Amazon Journal of Agricultural and Environmental Sciences, v. 59, n. 1, p. 54-59, 2016.

MANZANO, L. M. Recomendação de herbicidas na cultura da cana-de-açúcar baseada no potencial de sorção do solo e seu impacto econômico. Botucatu: Faculdade de Ciências Agronômicas, 2013.

MORAES, R. F. Agrotóxicos no Brasil: padrões de uso, política da regulação e prevenção da captura regulatória. Brasília, DF: IPEA, 2019. 
MOORE, D. M.; REYNOLDS, J. R. R. C. X-ray diffraction and the identification and analysis of clay minerals. 2. ed. Oxford: Oxford University Press, 1997.

MYERS, N.; MITTERMEIERF, R. A.; MITTERMEIERF, C. G.; FONSECAT, G. A. B.; KENT, J. Biodiversity hotspots for conservation priorities. Nature, v. 403, n. 6772 , p. $853-858,2000$.

NGUYEN, D. B.; ROSE, M. T.; ROSE, T. J.; MORRIS, S. G.; VAN ZWIETEN, L. Impact of glyphosate on soil microbial biomass and respiration: a meta-analysis. Soil Biology and Biochemistry, v. 92, n. 1, p. 50-57, 2016.

PACHECO, L. Atividade de herbicidas pré-emergentes em solos do Cerrado, na presença e ausência de resíduos orgânicos. Goiânia: Programa de Pós-Graduação em Agronomia (UFG), 2017.

PASSOS, A. B. R. J.; FREITAS, M. A. M.; TORRES, L. G.; SILVA, A. A.; QUEIROZ, M. E. L. R.; LIMA, C. F. Sorption and desorption of sulfentrazone in Brazilian soils. Journal of Environmental Science and Health - Part B: Pesticides, Food Contaminants, and Agricultural Wastes, v. 48, n. 8, p. 646-650, 2013.

RODRIGUES, B. N.; ALMEIDA, F. S. Guia de herbicidas. 7. ed. Londrina: $\mathrm{PbR}, 2018$.

SANTOS, H. G. Sistema brasileiro de classificação de solos. Rio de Janeiro: Embrapa, 2018.

SEEFELDT, S. S.; JENSEN, J. E.; FEURST, E. P. Loglogistic analysis of herbicide dose-response relationships. Weed Technology, v. 9, n. 2, p. 218-227, 1995.

SHANER, D. L. Field dissipation of sulfentrazone and pendimethalin in Colorado. Weed Technology, v. 26, n. 4, p. 633-637, 2012.

SILVA, E. E. da; AZEVEDO, P. H. S. de; DE-POLLI, H. Determinação da respiração basal (RBS) e quociente metabólico do solo (qCO2). Rio de Janeiro: Embrapa, 2007.

SILVA, G. S.; MELO, C. A. D.; FIALHO, C. M. T.; SANTOS, L. D. T.; COSTA, M. D.; SILVA, A. A. Impacto de sulfentrazona, isoxaflutol e oxyfluorfem sobre a microbiota de dois solos florestais. Bragantia, v. 73, n. 3 , p. 292-299, 2014.

TIRONI, S. P.; REIS, M. R.; SILVA, A. F.; FERREIRA, E. A.; BARBOSA, M. H. P.; COSTA, M. D.; SILVA, A. A.; GALON, L. Impact of herbicides on the microbial biomass and orthophosphate-solubilizing microrganisms in rhizosferic soil grown with sugarcane. Planta Daninha, v. 27, special issue, p. 1053-1062, 2009.

UNITED STATES DEPARTMENT OF AGRICULTURE (USDA). Soil Survey Staff. Soil taxonomy: a basic system of soil classification for making and interpreting soil surveys. 2. ed. Washington, DC: USDA, 1999. (Agriculture handbook, 436).

VANCE, E. D.; BROOKES, P. C.; JENKINSON, D. S. An extraction method for measuring soil microbial biomass C. Soil Biology and Biochemistry, v. 19, n. 6, p. 703-707, 1987.

VIEIRA, R. F.; SILVA, C. M. M. S.; SILVEIRA, A. P. D. Soil microbial biomass $\mathrm{C}$ and symbiotic processes associated with soybean after sulfentrazone herbicide application. Plant and Soil, v. 300, n. 1-2, p. 95-103, 2007.

VIVIAN, R.; REIS, M. R.; JAKELAITIS, A.; SILVA, A. F.; GUIMARÃES, A. A.; SANTOS, J. B.; SILVA, A. A. Persistência de sulfentrazone em Argissolo VermelhoAmarelo cultivado com cana-de-açúcar. Planta Daninha, v. 24, n. 4 , p. 741-750, 2006.

Emma Marris, 2010. "Conservation: Biodiversity as a bonus prize," Nature, Nature, vol. 468(7326), pages 895 895, December. 